\title{
PELAYANAN PENERBITAN SURAT IZIN TEMPAT USAHA( SITU ) PADA KANTOR PELAYANAN TERPADU KABUPATEN HULU SUNGAI UTARA
}

\author{
Agus Surya Dharma \\ Sekolah Tinggi Ilmu Administrasi (STIA) Amuntai \\ Email: Agus_Dharma_86@yahoo.co.id
}

\begin{abstract}
The Public Service is juring service by government, enterpreneur on government's nama or entrepreneur to society with or without payment for filling necessary or society needs.Based on prior research was found that there was lateness problem in completion to make SITU that exceed time from determined time in procedure operational standard of service integrated office Hulu Sungai Utara District. The Purpose of this research are to describe and analyze: (1) How process permission servise in publication of work place permission letter (SITU) in Hului Sungai Utara District. (2) Factors that influence service publishing of work plece permission letter.The approach of research is qualitative. The plece of research is in service integrated office in HSU District. The technique of collecting data is done by depth interview, observation and documentation. The analysis data uses interaction model by Miles and Huberman. The data testing is done with triangulation, that is technique triangulation although source triangulation. The result of research showed that servies of KPT HSU District in SITU service is high enough. This fact is appeared from (1) kid of apparatus sources and related with their skills. (2) The ease in submission is done well. It is announced dearly about making of permission letter procedure. (3) The accuracy of service that free from mestaker is well done. It canbe seen from there is no mestaker in every publication of fermission document. (4) The service cost in well enough. It is appeared from transparency about amount of payment with out more tax. (5) Many employees heve SLTA education so that their qualities in education aspect is felt still low enough.
\end{abstract}

Keywords: public service, performance, permission letter

\section{PENDAHULUAN}

Pelayanan Publik merupakan kegiatan pemenuhan kebutuhan pelayanan kepada masyarakat sesuai dengan amanat undangundang yang berlaku bagi semua penduduk atau warga negara atas barang, jasa atau pelayanan secara administratif yang dilaksanakan, oleh lembaga, koorporasi atau perusahaan yang memberikan layanan-layanan publik.

Meningkatnya dan semakin majunya otonomi daerah terus di kejar oleh pemerintah daearah agar bisa mewujudkan otonomi daerah yang diharapkan yakni otonomi yang benarbenar mandiri tanpa harus selalu bergantung dengan pemerintahan pusat dapat di kurangi secara perlahan dan sedikit demi sedikit.

Pelayanan publik merupakan sarana masyarakat untuk bisa mendapatkan sarana pelayanan, pelayanan yang bagus tentu akan memberikan nilai kepuasan tersendiri bagi masyarakat.

Dengan diberlakukannnya otonomi daerah ,daerah memiliki kewenangan membuat sebuah kebijakan daerah untuk mengatur dan memberikan pelayanan, peningkatan peran serta prakarsa dan pemberdayaan masyarakat yang bertujuan untuk meningkatkan kesejahteraan rakyat. Dengan memperhatikan hal tersebut maka pemerintah daerah memerlukan adanya prinsip. Prinsip yang nyata adalah prinsip yang menegaskan bahwa urusan pemerintahan dilaksanakan berdasarkan tugas, wewenang dan tanggung jawab. (Waluyo, 2007: 206).

Problema dalam penyediaan pelayanan perizinan, masih adanya alur birokrasi yang 
sering memberikan prosedur yang rumit dan kadang berbelit-belit, jika hal ini terus dibiarkan tetap bertahan dan berjalan tanpa ada perubahan yang dilakukan oleh pemerintah dalam sektor pelayanan ini, maka tidak menutup kemungkinan masyarakat menjadi malas dalam menanamkan modalnya dalam hal pembuatan perizinan

Pemerintah daerah diharapkan memberikan solusi terbaik bagi kelancaran dan kemajuan tingkat perekonomian masyarakatnya, salah satunnya dengan cara membuat pelayanan perizinan satu pintu, yang mana dalam hal ini proses pembuatan perizinan dilakukan hanya pada satu kantor tanpa harus keliling dari satu kantor ke kantor yang lainnya.

Seluruh kepala daerah telah di intruksikan oleh pemerintah pusat agar dapat segera menerapkan pola pelayanan perizinan terpadu satu pintu yang tertuang pada Permen Dalam Negeri nomor 24 Tahun 2006 tentang Pedoman Penyelenggaraan Perizinan Terpadu Satu Pintu, yang jenis kelembagaannya diserahkan kepada daerah untuk memilih jenis lembaga yang sesuai, bisa berbentuk dinas, kantor atau badan yang disesuaikan dengan kemampuan dan kebutuhan daerah dalam mengelolanya.

Taufik Taufik Effendi ( $2008: 83$ ), sebagai tindak lanjut dari upaya dalam peningkatan kualitas pelayanan publik, dilaksanakan pembentukkan sistem pelayanan terpadu dan layanan cepat, yang dibutuhkan oleh masyarakat sehingga masyarakat bisa mendapatkan pelayanan yang murah dan cepat.

Pelayanan terpadu ini sendiri bisa berbentuk pelayanan satu pintu dan pelayanan satu atap . pelayanan terpadu ini sudah diatur melalui permendagri No. 24 Tahun 2006 mengenai Pedoman Pelayanan Perizinan Satu Pintu.

Dengan adanya Kantor Pelaydalam peraturan ini, pelayanan atas permohonan perizinan dan non perizinan dilakukan oleh perangkat daerah penyelenggara pelayanan terpadu satu pintu, perangkat yang dimaksud adalah yang memiliki tugas pokok dan fungsi mengelola semua bentuk pelayanan perizinan dan non perizinan di daerah dengan sistem satu pintu.

Pelayanan perizinan dilakukan oleh lembaga teknis perangkat daerah dengan kewenangan yang diberikan sesuai dengan tugas dan fungsinya, mulai dari proses penerimaan permohonan, pemprosesan, penandatangan keputusan perizinan sampai dengan penerimaan pembayaran retrebusi perizinan

Guna mendukung tugas dan fungsi tersebut Pemerintah Kabupaten Hulu Sungai Utara telah membentuk Susunan Organisasi Kantor Pelayanan Terpadu yang dituangkan dalam Peraturan Daerah Kabupaten Hulu Sungai Utara Nomor 12 Tahun 2006 dan diperkuat dengan Peraturan Bupati Nomor : 13 Tahun 2006 tentang Pelimpahan Kewenangan Perizinan kepada Kantor Pelayanan Terpadu Kabupaten Hulu Sungai Utara. Hal ini dimaksud agar pelaksanaan Pelayanan/Perizinan akan lebih mudah dan cepat serta bermanfaat guna menyikapi tuntutan masyarakat Kabupaten Hulu Sungai Utara yang sebagian besar berkecimpung di bidang usaha jasa khususnya pada sentral perdagangan.

Dalam perjalanannya selama kurun waktu kurang lebih enam tahun, Kantor Pelayanan Terpadu Kabupaten Hulu Sungai Utara dalam menjalankan tugasnya yaitu melaksanakan kebijakan teknis di bidang pelayanan umum dan pelayanan perizinan kepada masyarakat terindikasi belum sesuai dengan harapan. Berdasarkan hasil observasi awal dengan melakukan wawancara dengan salah seorang informan yang mengatakan : Saya mengurus surat ijin tempat usaha, namun saya agak kecewa karena selesainya agak sedikit terlambat. (Hasil wawancara, Mei 2013).

Begitu pula ungkapan dari Ahmad Syarmada, anggota DPRD Kabupaten HSU yang menyatakan : ada beberapa warga yang menyampaikan keluhan terkait ketiadaan PNS diruang kantor saat jam kerja, karena tengah menghadiri undangan hajatan perkawinan dan semacamnya. Tidak ada satupun PNS di KPT yang ditemui untuk memberikan pelayanan kepada masyarakat, sementara keperluan warga untuk pengurusan ijin tersebut sifatnya sangat mendesak.(Sumber:http://www.antarakalsel.com diakses selasa, 19 Maret 2013).

Dalam pelaksanaan organisasi publik, penilaian kinerja organisasi merupakan suatu hal yang sangat penting, dengan adanya penilaian kinerja maka akan dengan mudah dilihat 
seberapa jauh tingkat pencapaiaan sasaran yang ingin dicapai, seberapa jauh pelaksanaan tugas yang telah di capai oleh petugas-petugas. Sebuah organisasi harus selalu mengukur kinerja lembaganya, apa lagi yang bersentuhan secara langsung dengan masyarakat sehingga bisa dengan cepat mengetahuai permasalahan yang muncul dan menjadi hambatan dilapangan.

\section{METODE PENELITIAN}

Pendekatan penelitian ini adalah pendekatan kualitatif dengan menggunakan metode Studi kasus yaitu untuk memberikan gambaran secara mendetail tentang latar belakang, sifat-sifat, karakteristik-karakteristik, yang khas dari Kinerja aparat pelayanan dalam memberikan pelayanan pubik. Dari hasil penelitian ini, kemudian dari karakteristik tersebut akan dijadikan penelitian suatu hal yang bersifat umum. Lokasi yang dipilih penulis menjadi obyek penelitian adalah Kantor Pelayanan Terpadu Kabupaten Hulu Sungai Utara. Hal ini ada beberapa pertimbangan sebagaimana yang disampaikan oleh Moleong (2002) bahwa cara terbaik yang perlu ditempuh dalam penentuan lapangan penelitian adalah dengan cara mempertimbangkan teori substansif, pergilah dan jajagilah lapangan untuk melihat apakah ada kesesuaian dengan kenyataan yang ada di lapangan. Berbagai keterbatasan waktu, biaya, tenaga, peralatan perlu pula dijadikan pertimbangan dalam penentuan lokasi penelitian. Sumber data adalah tempat atau asal data yang akan dipergunakan dalam penelitian ini diperoleh. Sumber data dalam penelitian ini adalah:

1. Data primer merupakan data asli yang memuat informasi atau data yang langsung diperoleh dengan menggunakan pedoman wawancara (interview guide) dari sumber data utama atau informan yaitu pegawai Kantor Pelayanan Terpadu Kabupaten Hulu Sungai Utara, masyarakat yang pernah menerima pelayanan dan informan lain yang mampu memberikan data secara akurat. Pemilihan informan dilakukan dengan cara purposive sampling. Sarman (2002:79) menyebtukan, " kalau purposive sampling yang dipilih, maka peneliti 'dengan sengaja' harus memilih sampel observasinya yang dipercaya akan dapat memberikan pemahaman komprehensif tentang gejala yang akan diteliti".

2. Data sekunder merupakan data pendukung yang diperoleh tidak secara langsung dari informan yaitu melalui dokumen, laporanlaporan dan sumber lainnya yang diperoleh dari Kantor Pelayanan Terpadu Kabupaten Hulu Sungai Utara.

Sumber data dipilih dengan menggunakan teknik purposive sampling.

Sebagaimana fokus penelitian, maka reduksi data dalam penelitian ini hanya diarahkan pada hal-hal yang bersangkut paut dengan kinerja kantor pelayanan terpadu dalam pelayanan pembuatan surat izin usaha perdagangan kabupaten Hulu Sungai Utara yang meliputi: sumber daya manusia aparatur, dan sarana prasarana kerja. Hal ini mengingat dalam hemat Miles dan Huberman (Wahyu dkk,2007:60), mereduksi data berarti merangkum, memilih hal-hal pokok, memfokuskan pada hal-hal yang penting, dicari tema dan polanya. Dalam mereduksi data, setiap peneliti akan dipandu oleh tujuan yang akan dicapai.

Kesimpulan awal yang dikemukakan masih bersifat sementara dan akan berubah bila ditemukan bukti-bukti kuat yang mendukung pada tahap pengumpulan data berikutnya. Tetapi apabila kesimpulan yang dikemukakan pada tahap awal didukung oleh bukti-bukti yang valid dan konsisten saat peneliti kembali ke lapangan mengumpulkan data, maka kesimpulan yang dikemukakan merupakan kesimpulan yang kredibel. Dalam setiap penelitian memerlukan standart untuk melihat derajat kepercayaan atau kebenaran dari hasil penelitiannya. penulis hanya menggunakan pengujian dengan cara Triangulasi, yaitu Triangulasi Sumber dan Triangulasi Teknik.Triangulasi sumber untuk menguji kredibilitas data dilakukan dengan cara mengecek data yang telah diperoleh melalui beberapa sumber. Pengecekan data dengan triangulasi sumber dalam penelitian ini dilakukan dengan melakukan wawancara pada pegawai dan masyarakat yang berbeda dari sebelumya. Teriangulasi Teknik untuk menguji kredibilitas data dilakukan dengan cara 
mengecek data kepada sumber yang sama dengan teknik yang berbeda. Misalnya data diperoleh dengan wawancara, lalu dicek dengan observasi atau dokumentasi.

\section{HASIL DAN PEMBAHASAN}

\section{Ketepatan Waktu}

Kepastian akan ketepatan waktu penyelesaian pelayanan sangat diharapkan oleh masyarakat. Apakah pelayanan yang yang diberikan sesuai dengan apa telah dijanjikan. Karna dengan kesuaain antara waktu yang dijanjikan dengan waktu penyelesaian ini merupakan sebuah tolak ukur bagi masyarakat dalam mendapatkan pelayanan atau pengurusan perizinan pada kantor tersebut. Dalam pelayanan diharapkan adanya batasan waktu yang bisa di tunggu oleh masyarakat guna mendapatkan apa yang mereka inginkan, sehingga ada kepastian dan kejelasan terhadap permohonan mereka.

Kantor Pelayanan Terpadu sebagai instansi pemerintah yang mempunyai tugas melaksanakan pelayanan umum. Diharapkan dapat memenuhi pelayanan sesuai dengan Peratutan Bupati Nomor 6 Tahun 2009. Dalam peraturan tersebut ditentukan lamanya waktu untuk menyelesaikan proses perijinan Surat Ijin Tempat Usaha adalah 3 ( Tiga ) hari, dengan catatan apabila masyarakat telah memenuhi semua persyaratan yang diwajibkan.

Dalam hal ini KPT Kkabupaten Hulu Sungai Utara dalam melakukan pelayanan publiknya masih dirasakan kurang, karna kadang masih terdapatnya penyelesaian surat perizinan tempat usaha hal ini dikarenakan petugas KPT menumpuk berkas dulu, setelah terpenuhi satu hari baru dibawa ke bagian teknis yang menangani. Hal ini tentunya bertentangan dengan apa yang diungkapkan oleh Parasuraman,et.al yang dikutip oleh Lupiyoadi (2001:148) Reliability (keandalan) adalah kemampuan perusahaan untuk memberikan pelayanan sesuai yang dijanjikan secara akurat dan terpercaya. Kinerja harus sesuai dengan harapan pelanggan yang berarti ketepatan waktu, pelayanan yang sama untuk semua pelanggan tanpa kesalahan, sikap simpatik dan dengan akurasi yang tinggi.

\section{Kemudahan Dalam Memajukan Permohonan}

Kemudahan dalam pengajuan permohonan terkait dengan persyaratan administrasi yang dibutuhkan. Dalam penerbitan surat ijin tempat usaha, Kantor Pelayanan Terpadu dengan jelas mensyaratkan tentang apa saja kelengkapan administrasi sebagai syarat untuk memproses perijinan.

Dalam hal ini kantor Pelayanan Terpadu sudah menjalankan seperti Keputusan Menteri Negara Pemberdayaan Aparatur Negara Nomor 63/KEP/M.PAN/7/2003 Tentang Pedoman Umum Penyelenggaraan Pelayanan Publik adanya Kesederhanaan yaitu ;

Prosedur pelayanan publik haruslah tidak berbelit-belit, mudah dipahami, dan mudah dilaksanakan oleh petugas sebagai pelaksana pelayanan maupun masyarakat sebagai penerima pelayanan publik;

Seperti yang di ungkapkan Gaspersz (1997) mengatakan tentang atribut dari sebuah kualitas pelayanan secara konvensional antara lain : ketepatan waktu, akurasi, kemudahan dalam pelayanan, kenyamanan dalam memperoleh pelayanan.

Namun masih ditemukan fenomena dimana pelanggan yang mengenal aparat akan lebih cepat dilayani dari pada masyarakat umum. Hal ini tentunya tidak sesuai dengan paradigma bahwa pelayanan publik harus bersifat terbuka dan tidak ada perlakuan diskriminatif.

\section{Akurasi Pelayanan Bebas Dari Kesalahan}

Dalam hal ini akurasi pelayanan, dapat dikatakan bahwa Kantor Pelayanan Terpadu Kabupaten Hulu Sungai Utara sudah cukup memenuhi harapan masyarakat. Hal ini terlihat dari out put yang dihasilkan. Dimana tingkat kesalahan minim dan kesedian untuk meperbaiki dan mengganti apabila terjadi kesalahan dalam penerbitan ijin.hal ini ditunjukkan dengan cepatnya respons pegawai apa bila terjadi kesalahan dari pihak mereka.

Menurut Gasper dalam Azis Sanapiah (2000:42), karakteristik atau atribut yang harus diperhitungkan dalam perbaikan kualitas jasa 
pelayanan antara lain adanya Akurasi pelayanan yaitu Akurasi pelayanan yang bebas dari kesalahan dalam pemprosesan dan hasil yang dikeluarkan oleh petugas pelayanan.

\section{Biaya Pelayanan}

Biaya pelayanan juga merupakan persyaratannya terjadinya suatu pelayanan publik yang berkualitas. Biaya yang harus dikeluarkan oleh masyarakat untuk penerbitan SITU telah diatur dalam peraturan bupati nomor Nomor 13 Tahun 2006. Untuk ini Kantor Pelayanan Terpadu semua dilakukan dengan trasparan dan terbuka dimana KPT Kabupaten Hulu Sungai Utara melakukan pembayaran biaya pelayanan secara terbuka di loket tersendiri yang diterima oleh bendahara peneriman KPT Kabupaten Hulu Sungai Utara pembayaran ini pun bisa dilihat oleh masyarakat umum.

Hal ini juga setara dengan apa yang diungkapkan dalam Standar Pelayanan Publik menurut Keputusan Menteri PAN Nomor 63/KEP/M.PAN/7/2003, sekurang-kurangnya meliputi:

1. Prosedur pelayanan;

2. Waktu Penyelesaian;

3. Biaya Pelayanan;

4. Produk Pelayanan;

5. Sarana dan Prasarana;

6. Kompetensi petugas pelayanan

\section{Faktor-Faktor Yang Mempengaruhi Pelayanan}

\section{a. Struktur Organisasi}

Menurut Hasibuan (1996) yang dimaksudkan dengan struktur organisasi adalah gambar yang memberikan gambaran tipe sebuah organisasi, kedudukan beserta dengan wewenang pejabat, bidang serta hubungan pekerjaan, garis komando, tanggung jawab dan sistem pimpinan organisasi tersebut.

Edwad (Winarno, 2007) mengatakan “" struktur birokrasi yang bertugas mengimplemintasikan kebijakan memiliki pengaruh yang signifikan terhadap implemintasi kebijakan ". Dalam pembahasan mengenai struktur organisasi ini, akan dimulai dari konsep sesungguhnya struktur organisasi dalam penelitian ini adalah merupakan sebuah susunan bagian-bagian yang mempunyai tugas dan fungsi serta wewenangnya masing-masing akan tetapi saling berhubungan serta memiliki tanggung jawab dalam hal pelayanan publik

Suatu struktur organisasi tidak sama dalam setiap daerah dan lembaga yang menjalankannya, perlu pemilihan yang selktif dalam pembuatan struktur organisasi, sehingga bisa mengahasilkan bentuk susunan organisasi yang efektif.Agar kekuatan yang ada bisa menutupi kelemahan yang akan muncul. Minzberg ( dalam Sedarmayanti, 2000) mengungkapkan :

1. Simple Structure (struktur sederhana). Struktur ini terdiri dari lima komponen utama yaitu manajemen puncak, manajemen mengah, teknostruktur, staf pendukung dan pelaksana.

2. Machine Bureucracy (birokrasi mesin) model ini standarisasi tugas merupakan ciri utama tugas tugas rutinitas, formalisasi, aturan atau prosedur, departemenisasi fungsi, pemusatan wewenang, serta pembutan sebuah keputusan untuk dilaksanakan oleh bawahan melalui intruksi administrative yang membedakan fungsi lain dan fungsi staf, yang merupakan ciri pokok dari birokrasi mesin.

3. Profesional bureucracy model ini merupakan kombinasi antara standarisasi dan desentralisasi. Yang mana aparat dalam organisasi ini dituntut untuk memenuhi persyaratan kualifikasi keahlian yang tinggi, karna optimalisasi pelaksanaan tugas sebagai acuan utama.

4. Divisional Structure model ini secara umumdikenal sebagaimana yang telah banyak dicontohkan oleh banyak bentuk organisasi yang borokrat, dimana dalam satuan fungsional itu ada tugas yang sangat ketat.

5. Adhocracy pada model ini, peran staf profesional tampak menunjol, diferensiasi horizintal sangat besar, sedangkan diferensiasi vertikal sangatlah rendah. Pada model ini tidak mengenal departemenisasi yang permanen, formalitas hampir tidak ada. Akan tetapi desentralisasi kewenangan sangat kuat, fleksibilitas dan daya tangkap tinggi. 
Dari hasil penelitian diperoleh bahwa Kantor Pelayanan Terpadu Kabupaten Hulu Sungai Utara telah memiliki struktur organisasi dan tata kerja yang jelas meskipun untuk petugas loket merupakan pegawai dari isntansi induk masing-masing.

Terkait dengan kewenangan KPT, hal ini sangat berdampak pada semakin besarnya kewenangan instansi pelayanan, yang akan mendorong dan memantapkan terlaksananya fungsu KPT sebagai unit pelayanan satu pintu, yang mana setiap unit kerja dari masing-masing instansi berada di Kantor Pelayanan Terpadu tersebut, setiap ada permohonan pelayanan dapat langsung di proses. Tanpa harus ke kantor atau instansi yang berkaitan.

Struktur organisasi pemerintah dicirikan dengan adanya Badan, Dinas dan Kantor dan unit kerja masingsing-masing dan tentunya memiliki tugas dan fungsi yang berbeda pula. Walaupun tugas dan fungsinya berbeda-beda tetapi keseluruh unit kerja tersebut bersamasama menunaikan tugas pemerintahan yang mengarah pada tujuan tertentu.

Sesuai dengan hal tersebut, Ndraha (2003) mengemukakan fungsi koordinasi sebagai " proses penyepakatan bersama berbagai kegiatan atau unsur yang berbeda-beda sedemikian rupa, sehingga disis yang satu, semua kegiatan atau unsure itu terarah pada pencapaiaan suatu tujuan yang telah ditetapkan, disisi lain supaya keberhasilan kegiatan yang satu tidak merusak keberhasilan kegiatan yang lain".

Sebagai tindak lanjut terbitnya Peraturan Daerah Kabupaten Hulu Sungai Utara Nomor Nomor 12 Tahun 2006, tentang Pembentukan Struktur Organisasi dan Tata Kerja Kantor Pelayanan Terpadu Kabupaten Hulu Sungai Utara.maka koordinasi antar instansi terkait mutlak diperlukan dalam rangka mendukung implementasi pelayanan perijinan kepada masyarakat, yang disertai dengan adanya prasara yang mendukung pelayanan publik yang berkualitas.

Hal ini sangat di dukung oleh oleh dinas atau instansi yang terkait tentang keperluan pelayanan publik yang diperlukan oleh masyarakat, sehingga semua instansi terkait tentang perijinan maupun yang non perijinan bersedia menempatkan para pegawai yang berkopeten dan sesuai dengan kemampuan tugasnya.

\section{b. Kemampuan Aparat}

Dalam pembahasan mengenai kemampuan aparat ini, akan diawali dari konsep kemampuan aparat dalam melakukan pelayanan publik yang baik. Dalam hal ini peneliti kemampuan para aparat yang menunjukkan pengetahuan, kemampuan dan kemauaan dari aparat dalam melaksanakan tugas demi kelancaran pelayanan publik.

Moerdiono (1988) mengatakan aparatur pemerintah adalah seluruh jajaran pelaksana pemerintah yang memperoleh kewenangannya berdasarkan pendelegasian dari Presiden Republik Indonesia.

Dengan kata lain aparatur merupakan orang-orang yang melaksanakan atau menjalankan roda pemerintahan. Aparatur memili sebuah peran yang strategis dimana mereka memegang tugas-tugas baik pada sektor pemerintahan maupun sektor pembangunanan. Apartur ini merupakan organisasi kepegawaian dalam hal penyelenggaraan administrasi pemerintahan yang melayani masyarakat. Aparatur sangat diperlukan oleh negara guna menjalankan aspek-aspek pemerintah berdasarkan kemampuan dan keahliannya masing-masing.

Pada kontek ini diharapkan kemampuan aparat dalam melakukan pelayanan publik baik itu dari segi pengetahuan, dan keterampilan terhadap tugas dan fungsinya serta sikap yang baik kepada masyarakat dalam pelayanan publik sesuai dengan tuntutan pelayanan. Keterampilan sangat diperlukan kaina berkaitan dengan tugas.

Berdasarkan hal tersebut, tingginya kemampuan aparat dalam mendukung terciptanya kualitas pelayanan yang semakin baik. Akan tetapi malah sebaliknya apabila kemampuan aparatnya rendah maka ini akan menjadi bomerang dan penghambat terciptanya pelayanan yang cepat, tepat dan berkualitas sesuai dengan harapan. Kemapuan aparat yang diharapkan disini meliputi pengetahuan, pengertian, ketelitian, teknik-teknik, kebijakan, prosedur kerja yang berkaitan dengan fungsi dan tugas tangungg jawabnya sesuai dengan tugas yang ditanganinya. 
Kinerja organisasi yang menunjukkan performace organisasi seringkali tidak terlepas dari beberapa faktor yang mampu memberikan corak terhadap organisasi. faktor yang lazimnya mempengaruhi kinerja suatu organisasi menurut Pasolong (2008:186) terbagi kepada beberapa hal salahsatunya sebagai berikut :

Kemampuan Menurut Iskandar (Pasolong, 2008:186), bakat adalah merupakan suatu karakteristik unik individu yang membuatnya mampu melakukan suatu aktivitas dan tugas secara mudah dan sukses.

Dari hasil pengamatan peneliti, ternyata tingginya tingkat pendidikan seorang aparat tidak serta merta akan menjamin semakin baik kemampuan dan tingkat pemahaman dalam melaksanakan tugasnya. Faktor lain dalam mendukung adalah kematangan aparatur pegawai yang ada, dengan makin lama seseorang aparatur bekerja dalam suatu instansi maka kemampuannya semain baik hal ini dikarenakan mereka sudah hapal dan tahu apa yang mereka lakukan, dan kalau pun juga ada peraturan yang baru mereka tinggal memperbahrui dan meningkatkan pengetahuan yang telah mereka milik . Tingkat kematangan ini diartikan sebagai kemampuan dan kemauan seseorang untuk mengarahkan prilakunya sendiri. Kematangan berkaitan dengan kesiapan dalam melaksanakan tugas yang bermuara pada prestasi kerja. Seorang aparatur harus siap berkerja dimana pun mereka akan di tempatkan jangan sampai disaat penempatan kerja yang baru seorang aparatur bingung bahkan merasa mereka tidak bisa bekerja di tempat yang baru dengan alasan bukan profesi yang dimilikinya.

\section{c. Sistem Pelayanan}

Sistem pelayanan juga faktor penentu terjadinya pelayanan publik yang baik, sistem pelayanan merupakan serangkaiaan yang saling kait mengait seperti mata rantai yang tak bisa terpisahkan antara yang satu dengan yang sehingga membentuk kebulatan dalam memberikan pelayanan yang terbaik kepada masyarakat sesuai tujuan organisasi.

Berkaitan dengan hal ini maka. Peraturan Bupati Nomor 13 Tahun 2006 menyebutkan bahwa untuk bisa memberikan pelayanan perijinan yang prima kepada masyarakat diperlukan adanya sarana dan prasarana yang respensitatif guna menunjang pelaksanaan tugas yang optimal pada masyarakat.

Menurut Monier (1998) sarana pelayanan merupakan semua jenis peralatan kerja dan fasilitas lain yang berfungsi sebagai alat utama / bantu dalam pelaksanaan pekerjaan. Berkenaan dengan hal tersebut, maka dalam rangka peningkatan pelayanan. Maka KPT melakukan pelengkapan terhadap sarana dan prasarana pelayanan mereka baik itu komputer yang mendukung pelayanan, telpon dan fexsimel sebagai fasilitas komunikasi dan kendaraan operasional untuk kelancaran mobilitas pegawai.

Untuk kejelasan informasi tentang pelayanan di KPT Kabupaten Hulu Sungai Utara sudah baik dengan pemanfatan papan pengumuman di awal masuk ruangan guna pemberitahuan bagi masyarakat yang pertama kali mengurus tentang perijinan mau pun non perizinan.

Sistem pelayanan pada kantor pelayanan terpadu juga sudah baik hal ini yang mana untuk memberikan kemudahan pada masyarakat, loket pelayanan dibuat dalam bentuk terbuka dengan meja pelayanan yang memanjang, sehingga masyarakat dapat langsung bertatap muka dengan para petugas pelayanan penerimaan berkas yang tentu sesuai dengan jenis perijinan yang akan di proses, sedangkan ruang pemeroses ditempatkan berdekatan dengan meja pelayanan yang dilengkapi dengan sejumlah komputer yang cukup sehingga waktu dan tenaga yang digunakan dapat lebih efisien dan efektif

Berkaitan dengan upaya untuk meningkatkan pelayanan, maka KPT Kabupaten HSU juga melaksanakan Sosialisasi dan penyebarluasan informasi melalui media cetak maupun elektronik, bahkan KPT Kabupaten Hulu Sungai Utara juga melakukan sosialisasi kemasyarakat baik yang berada di kabupaten atau pun yang berada di kecamatan secara langsung sehingga masyarakat tahu dengan jelas mekanisme dan prosedur perijinan tentunya dengan kualitas pelayanan yang diberikan kepada masyarakat.

Dalam kantor pelayanan terpadu sendiri sudah terpampang dengan jelas bagaimana alur dan proses yang harus dilakukan dari mana proses pemasukkan berkas sampai dengan 
proses terbitnya surat perijinan tersebut, hal ini dimaksudkan agar sistem pelayanan yang diberikan oleh kantor pelayanan terpadu kabupaten hulu sungai utara bisa di ketahui, dipahami dan dimengerti oleh masyarat tanpa harus bertanya kepada petugas.

Pada dasarnya pelayanan publik yang diberikan kepada masyarakat dapat diketahui dengan cara membandingkan persepsi masyarakat atas service pelayanan yang mereka inginkan dengan apa yang mereka dapatkan dilapangan. Bilamana pelayanan yang diberikan oleh aparat dalam prakteknya yang diterima oleh masyarakat sama dengan harapan atau keinginan mereka, maka pelayanan tersebut dikatakan sudah memuaskan ( Zeithaml,et.al, 1990 )

\section{KESIMPULAN}

Berdasarkan hasil dan analis data penelitian berkaitan dengan pelayanan penerbitan Surat Izin Tempat Usaha, maka dapat disimpulkan hal-hal sebagai berikut :

Pelaksanaan Pelayanan Penerbitan Surat Izin Tempat Usaha ( SITU ) di Kabupaten Hulu Sungai Utara sudah berjalan dan terlaksana dengan baik, Hal ini dapat dilihat; Pertama : Ketepatan Waktu Pelayanan sudah cukup baik hal ini dapat dilihat proses penyelesaian perizinan sesuai dengan ketentuan yang telah berlaku. Kedua: Kemudahan dalam mengajukan permohonan, dalam hal ini KPT Kabupaten Hulu Sungai Utara dengan jelas memaparkan dan memeberikan penjelasan tentang kelengkapan sehingga memudahkan masyarakat yang ingin mengajukan permohonan, Ketiga, Akurasi Pelayanan Yang Bebas dari Kesalahan Kantor Pelayanan Terpadu Kabupaten Hulu Sungai Utara sudah baik dimana pelayanan yang diberikan sangat jarang terjadi sebuah kesalahan, kalupun ada maka akan langsung ditindak lanjuti, Keempat, Biaya pelayanan, untuk biaya pelayanan kantor pelayanan terpadu tidak pernah memungut melebihi ketentuan yang telah ditentukan dan secara transparan biaya tersebut di tuliskan dipapan pengumuman.

Beberapa faktor yg menyebabkan pelayanan KPT belum terlaksana dengan baik yaitu Masih terbatasnya kewenangan KPT yang
Cuma sebagai penerima berkas saja, masih kurangnya sarana prasarana pelayanan dan belum adanya pemanfaat media informasi teknologi faktor penghambat lainnya banyaknya pegawai yang lulusan SLTA sehinggga menyebabkan kurangnya kualitas pegawai kalu dilihat dari segi pendidikan.

\section{REFERENSI}

Abidin, S.Z. 2004. Kebijakan Publik. Jakrta, Penerbitan Pancur Siwah

Gasperz, V. 1994. Manajemen Kualitas. Jakarta. Gramedia

Moenir, AS, 2006. Manajemen Pelayanan Umum di Indonesia, Jakarta: Bumi Aksara

Moeleong, Lexy.J, 2000, Metodologi Penelitian Kualitatif, PT. Remaja Rosdakarya, Bandung.

Pusat Kajian Kinerja Kelembagaan Lembaga Administrasi Negara, 2004, Teknik Penyusunan Kinerja/Berkinerja Tinggi, Cetakan Pertama, LAN, Jakarta.

Ratminto, Atik Septi Winarsih, 2005, Manajemen Pelayanan, Cetakan I, Pustaka Pelajar, Yogyakarta.

Robbins, P. Stephen, 2002, Teori Organisasi, Struktur, Desain dan Aplikasi, Arcan (Terjemahan), Jakarta.

Thoha, M. 1998. Dimensi-Dimensi Prima Ilmu Administrasi Negara. Jakarta: PT. Raja Garpindo Perkasa.

Thoha Miftah. 2001, Perilaku Organisasi, Konsep Kontroversi, Aplikasi, Prenhallindo (terjemahan), Jakarta.

Wibowo, Samodra, 1994, Kebijakan Publik Proses dan Analisa, Intermedia,Jakarta.

Winarno, B. 2007. Teori dan Proses Kebijakan Publik, Jakarta : Medprees

Zeithalm, V.A (et.al) 1990. Balancing Customer 
Perceptions and Expectations. New York. The Free Pres, A Division of Macmillan Inc.

Peraturan Menteri Dalam Negeri Nomor 24 Tahun 2006 tentang Pedoman Penyelenggaran Satu Pintu.

Peraturan Daerah Kabupaten Hulu Sungai Utara Nomor 12 Tahun 2006 tentang Pembentukan Struktur Organisasi dan Tata Kerja Kantor Pelayanan Terpadu Kabupaten Hulu Sungai Utara.

Peraturan Bupati Kabupaten Hulu Sungai Utara Nomor 13 Tahun 2006 tentang Pelimpahan Kewenangan Perizinan Kepada Kantor Pelayanan Terpadu Kabupaten Hulu Sungai Utara. 